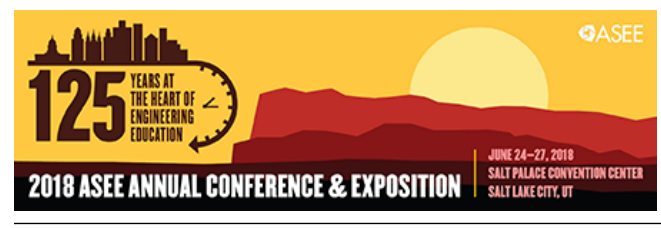

Paper ID \#23808

\title{
The Effectiveness of a Multi-year Engineering Enrichment
}

\section{Dr. Linda Hirsch, New Jersey Institute of Technology}

LINDA S. HIRSCH is the Assistant Director for Research, Evaluation and Program Operations for the Center for Pre-College programs at New Jersey Institute of Technology. Dr. Hirsch has a degree in educational psychology with a specialty in Educational Statistics and Measurement from the Graduate School of Education at Rutgers University. She has been involved in all aspects of educational and psychological research for over 20 years. Dr. Hirsch has extensive experience conducting longitudinal research studies and is proficient in database management, experimental design, instrument development, psychometrics and statistical programming. 


\title{
The Effectiveness of a Multi-Year Engineering Enrichment Program for Middle School Girls - Research to Practice
}

\begin{abstract}
Prior research comparing aspects of single-gender (female-only \& male-only) summer enrichment programs to equivalent mixed-gender programs found female-only programs to be effective in educating young girls about engineering, positively influencing their perceptions of engineers and attitudes toward engineering as a career. A more recent examination of gains in content knowledge, self-efficacy, beliefs about gender equity and qualitative perceptions of engineers using the Middle School Attitudes toward Engineering, Knowledge of Engineering Careers Survey and the Draw an Engineer Test in equivalent post-4th grade, 2015 summer programs found significantly positive results: females in the single-gender program showed greater improvement in engineering content knowledge than females in a mixed-gender program, as well as significant increases in self-efficacy and perceptions that women can be engineers. Each program accepts 25 students, with priority given to returning students. A follow-up study was conducted during the summer of 2016 to determine if changes in girls' attitudes towards engineering, perceptions of engineers and gains in content knowledge were sustained. A majority of the students who participated during 2015 returned for the post-5th grade program in 2016 with 50\% more new students. Comparisons amongst the 2016 mixed- and single-gender programs and between the 2015 and 2016 programs showed sustained effects for returning students, especially girls, and a greater 2016 impact for girls who participated in the 2015 singlegender program. A third year follow-up was conducted during the summer of 2017. Of the 25 girls who participated in the post-6th grade program, 10 of them had previously attended the post-4th grade and post 5th grade programs during the summers of 2015 and 2016 respectively. An additional 5 girls attended the post 5 th grade program during the summer of 2016. In addition to repeating the same follow-up evaluation(s) performed in 2016, with further positive results, parents of returning students were asked to respond to a survey regarding their child's school performance and interest in a STEM career. Eighty-three percent of the parents whose daughter had previously attended the female-only program for either one or two summers reported that her grades in mathematics and science had improved and $96 \%$ reported that she had expressed an interest in further STEM studies since attending the previous summer.
\end{abstract}

\section{Introduction}

The Bureau of Labor Statistics reported that the demand for more engineers in the workforce is growing at a rate faster than the overall workforce, requiring at least a half a million more engineers by the year 2022 [2]. In addition, the progressive retirement of the baby boomer generation will result in the loss of just as many engineers, creating a need for more than a million engineers to enter our workforce in the next five years [1]. Unfortunately, not enough students are entering engineering programs in college and thus are not pursuing careers in engineering [7-8]. Two of the more critical reasons for this are the absence of engineering topics in K-12 science, technology and mathematics curriculum [9-13] and the chronic underrepresentation of women [8,14-17] and minorities [8,17-18]. 
The Need for Effective STEM Education: Too many students lack an interest in engineering, due in part to a general lack of public knowledge about what engineering is and what engineers actually do [19], but more critically, the lack of truly integrated Science, Technology, Engineering and Mathematics (STEM) curriculum [12-13, 20-21] in K-12 classroom instruction. Unfortunately, a majority of teachers are ill-prepared to present what engineering curriculum they may have in their classroom [22-23]. As a result, most K-12 students do not experience practical applications of engineering and are not able to make the connection between mathematics, science and engineering in the real world [24-25].

Proper academic preparation for college should begin as early as middle school, if not the late elementary grades [7] particularly if students are to be prepared to enter programs in STEM [912, 26-27]. In addition to not receiving the appropriate instruction within their school, most students are not properly advised as to how to prepare for careers in STEM, particularly engineering [24]. Middle school students, who do not learn about the benefits of becoming an engineer, never consider studying engineering and are therefore not motivated to prepare academically to enter engineering programs in college [25], and are often unsuccessful if they develop an interest in engineering in their later high school years [28].

Participation in STEM programs outside of regular classroom instruction, such as the Early College Preparatory Programs offered by the Center for Pre-College Programs at New Institute of Technology $[10,13,29]$ during the summer, can be extremely effective in informing students about career options in STEM, particularly engineering [19], increasing their interest in STEM related studies. In turn, increased interest motivates students to seek academic advice which helps ensure they receive the preparation required to enter STEM programs in college [29-30].

The Underrepresentation of Women and Minorities: Women occupy nearly half the United States workforce but less than $25 \%$ of the STEM workforce [13,17]. Less than $15 \%$ of engineers are women $[8,16]$. The majority of STEM professionals in the US are Caucasian $(75 \%)$ and approximately $15 \%$ are Asian. The remaining $10 \%$ are; 3\% black, $4 \%$ Hispanic and 3\% all others. Less than $10 \%$ are minority women [31].

High school graduation rates are increasing with a nationwide graduate rate of 78\% [32] but college enrollment rates have fallen, especially for low-income and minority students [33]. And although more than half of college degrees are awarded to women the majority of the degrees in STEM fields, particularly engineering, are earned by men $[2,8]$. If women pursued careers in engineering at the same rate as men, the current and impending shortage of engineers in the US workforce would not be nearly as critical [34-36]. Considerable effort has focused on increasing the participation of women in all the STEM fields with much less success in engineering [21, 29, 35]. There has been considerable increase in the number of women pursuing careers in mathematics and science, but engineering remains a male dominated occupation [2]. Women find the work environment in engineering unwelcoming [36], inconsistent with their values [37], and do not necessarily see the societal benefits of engineering [38].

Hispanics are the nation's largest minority group with a lower high school graduation rate of approximately $70 \%[32,39]$. The graduation rate for African American students is even lower, approximately $66 \%[32,35]$. Overall college enrollment rates decreased from $69 \%$ to $66 \%$ between 2008 and 2013 with an estimate of only $46 \%$ for low-income students [32]. Because high proportions of Hispanic and African American girls come from low-income backgrounds the college enrollment rate for those who graduate from high school are significantly lower than 
for other girls, particularly Caucasians [39-40]. High proportions of African American girls attend schools without quality resources or extracurricular activities and have limited opportunities to enroll in STEM courses or STEM-related activities [40]. Hispanic girls face the same low-income hurdles and are often placed in remedial classes because English is not their primary language [39]. All limiting the number of women entering engineering programs in college or careers in engineering.

\section{Background on Single Gender Education}

Single-gender education was originally intended for affluent students, mostly boys, but by the 1970's educators began to offer the same educational options for girls due primarily to the developing gender gap between the academic achievement of boys and girls [41]. Considerable research exists describing the many benefits of single-gender education for girls, signifying increased confidence, being more likely to ask questions, and maintaining behaviors that tend to disappear due to male dominance in the classroom [42]. Studies of student behavior(s) and student-teacher interactions in co-educational classrooms document teachers' differential treatment of boys and girls, for example, being more tolerant of boys' disruptive behavior and encouraging boys to solve problems on their own while helping girls who have trouble or adjusting their teaching strategies to accommodate typical male traits [43-44], further suggesting the benefits of single-gender education.

Single-gender research focused on boys has found the climate in all-male classrooms to be much different than that in all-female classrooms [45-46]. The increased use of technology, more opportunities for physical activity, the presence of male role models in the classroom and the altering of teachers' instructional methodology to accommodate maleness have all been found to be beneficial for boys' learning [47-48].

In contrast, there is a substantial amount of literature summarizing investigations of singlegender education that suggests otherwise [41]. Much of the research is not rigorous or scientifically based, and tends to focus on private and Catholic schools where subjects are basically self-selected [41] and provide no strong conclusions supporting or dismissing the overall benefits [49]. Researchers have begun to recommend that there should be a clear rationale with specific goals for single-gender education [50-52]. Summer enrichment programs like the Women in Technology Initiative, designed with the goal to increase the number of women interested in engineering and other technological careers in an atmosphere free from male dominance are consistent with this recommendation [53-55] and findings that single-gender learning experiences increase girls' self-esteem and broadens their career aspirations [56-57].

\section{Woman in Engineering Initiative}

Middle school is an important time for students to begin thinking about future careers, and research has found that many students form opinions about the career paths they will take as early as 13 [58-59]. Because boys and girls do not differ much in academic abilities or in their interest in STEM subjects until their high school years but rather in their attitudes toward technological careers like engineering [60-61] it is especially important for girls [62-64]. Unfortunately girls begin to develop negative attitudes toward STEM subjects in the later middle school and high school years [62-64], particularly when it comes to engineering. By the latter middle school years, girls start underestimating their own technical abilities and begin to place more importance on being popular rather than academic performance [37, 60, 62, 65-66]. During high school they enroll in fewer mathematics and science courses, and thus lack the background 
needed to enroll in college STEM programs [62, 66-69]. Early intervention is needed to address this problem because once students, particularly females, reach college; it is too late to prepare $[62,69-71]$.

In response to this, considerable research has found that providing young girls with a positive STEM-related experience in middle school, before they develop negative attitudes or lose interest, can have a positive influence on their interest level and intent to pursue studies in STEM $[19,55,72-78]$. While increased interest and positive attitudes are beneficial to learning [79], very little research exists demonstrating the long-term effects of these experiences in terms of college attainment and career paths [80].

Women prefer careers in which they can make a difference in the world [81] and historically women have not seen that engineers and developments in engineering improve our lives [82] or make a difference in the world [83]. The public face of engineering is male dominated [84] and masculine [85]. Young girls need to learn the importance of engineering and that women can be just as effective and successful in an engineering career as men. Self-efficacy is important in all pursuits [86], but especially important for women to persist in engineering [87-88]. Young girls need to develop an engineering identity if they are to feel a sense of belonging and success in pursuing a career in engineering [89], and the earlier the better [19, 60, 62, 72, 87-88].

The Woman in Engineering Initiative in the Center for Pre-College Programs, which is still called FEMME for the original name, "Females in Engineering: Methods, Motivation and Experiences", was designed specifically for young girls in an effort to increase the number of women interested in engineering and other technological careers. Although research on the benefits and relative effectiveness of single-gender education remains inconclusive, considerable research does describe many benefits of single-gender education for girls in addition to improved academic performance, including increased confidence and self-efficacy, being more likely to ask questions, and maintaining behaviors that tend to disappear due to male dominance in the classroom [90]. In the absences of truly integrated STEM curriculum in K-12 classrooms through which girls learn the importance of engineering and its relevance to the world around them, considerable efforts have been made to introduce them to engineering through outreach programs, after school programs or clubs and summer camps [19, 38, 75, 77-78, 83], but many of these efforts are short-term, lasting only a day, perhaps a week [73].

The FEMME programs runs five days a week, 9:00 a.m. to 3:30 p.m. Monday through Friday for four weeks during the month of July. Girls can begin attending the FEMME Program during the summer after $4^{\text {th }}$ grade, and return in subsequent summers through $9^{\text {th }}$ grade. Each grade level from $4^{\text {th }}$ through $9^{\text {th }}$ grade focuses on a different field of engineering as follows:

FEMME 4: Environmental Science and Engineering - designed to provide post-fourth grade girls with an introduction to Environmental Science and Engineering.

FEMME 5: Aeronautical Engineering - designed to provide post-fifth grade girls with an introduction to Aeronautical Engineering.

FEMME 6: Mechanical Engineering - designed to provide post-sixth grade girls with an introduction to Mechanical Engineering.

FEMME 7: Chemical Engineering - designed to introduce post-seventh grade girls to Chemistry and Chemical Engineering principles and to learn how chemical engineers create better ways of doing things and find the best possible way to manufacture products. 
FEMME 8: Biomedical Engineering Program - designed to provide post-eighth grade girls with an introduction to Biomedical Engineering, a discipline that integrates the engineering sciences with the biomedical science and clinical practices.

FEMME 9: Computer Coding: - designed to provide post-ninth grade girls with an introduction to computer coding and computer engineering.

Continued participation in FEMME allows girls to form relationships and feel they are part of a community. Research on girls in engineering has found that social support of this type is important if they are to persist $[37,91]$. Through integrated STEM curriculum that focuses on applications of engineering, as recommended in the Next Generation Science Standards (NGSS) [92], girls learn about the importance of engineering and how it relates to everyday life. The girls also visit research laboratories and manufacturing facilities where they meet women engineers and learn first-hand about their careers in engineering. Having female role models in the classroom and interacting with female engineers in the field are also consistent with factors that lead to persistence $[38,77,91]$.

\section{Summary of Evaluations to Date}

Early evaluations of the FEMME program(s) were positive and mostly formative in nature [9394]. Subsequent evaluations were more quantitative and continued to yield positive results [9596]. More recent evaluations were developed to be more rigorous and found that girls who participated in FEMME had significantly more positive attitudes toward STEM, particularly engineering, significantly more knowledge about careers in engineering and what engineers actually do compared to other students from similar backgrounds [97-100]. Recent, more qualitative evaluations using the Draw an Engineer test to examine girls' perceptions of engineers including gender attributions and their own self-efficacy have found interesting and positive results [101-102].

The Early College Preparatory Programs also offers mixed-gender programs equivalent to the FEMME programs which until recently meant that approximately $70 \%$ of the students accepted into our summer enrichment programs were female. Marked increases in applications from elementary and middle school boys in varying degrees prompted the addition of some all-male programs each summer. The mixed-gender and single-gender programs (male-only and femaleonly) within a grade level are identical with respect to curriculum, field trips, classroom activities and teachers. Different subjects or activities are taught by different teachers such that teachers rotate what they teach through each of the programs (i.e. communications, engineering, computers, science and mathematics).

Comparisons among female-only (FEMME), male-only and mixed-gender programs, 2012: The first summer that all three gender-grouped programs were offered was 2012 for post $4^{\text {th }}$ and $5^{\text {th }}$ graders. A semi-qualitative and objective evaluation examined differences in classroom climate, changes in students' attitudes toward STEM, increases in content knowledge, changes in students' perceptions of what engineers actually do and their gender attributions. During the programs the teachers were interviewed to collect qualitative information about differences in classroom climate and student behavior among the three types of programs (female-only, maleonly and mixed-gender). Of particular interest were student interactions during the engineering classes and activities. Students' attitudes toward STEM and knowledge of careers in engineering were measured using the Middle School Attitudes to Mathematics, Science and Engineering Survey developed and validated by Center for Pre-College Programs staff and used extensively 
to evaluate program effectiveness [103]. The Draw an Engineering Test [104] was used to measures students' perceptions of engineers, including gender identity and what they actually think engineers do. Studying students' spontaneous drawings of engineers is very informative and can be used to demonstrate changes in their perception of engineers.

Students are asked to draw a picture of an engineer at work and write a short sentence about what the engineer in the picture is doing. Students' drawings of engineers at work are examined and coded to describe the gender attribution of the engineer and the overall action or meaning of what the engineer was doing. Verbiage in the sentence students provide about what the engineering is doing is examined for key words such as designing, fixing, building, testing, modelling, prototype, drawing blue prints, etc and for the use of "it, he, she, my, or the" to help identify the gender of the engineer. Students often draw a stick figure with no gender or a person with only legs protruding out from under a car or a pair of arms mixing chemicals. When a stick figure, androgynous person or partly hidden person is drawn and described as "it", "my engineer" or "the engineer" in the sentence then the gender of the engineer is coded as unknown. Not all students wrote a sentence and the action and meaning had to be inferred from the drawing as well as the gender when possible.

Differences in Classroom Climate: The teachers described the girls in the FEMME program as cooperative, communicative, much more task-oriented and less competitive than the boys in the all-male group with much less physical activity during group work. The boys were much more active and less cooperative than the girls requiring more discipline and suggestions to stay on task. One teacher explained that girls' solutions to problems were not necessarily better than the boys', nor did they appear to complete tasks more quickly than the boys but that the girls were "serious and more focused". The girls were "less competitive and more willing to share and help each other than the boys". Teachers also agreed that the classroom atmosphere in the singlegender programs was very different than in the mixed gender programs. In the mixed-gender programs ( $42 \%$ female; $58 \%$ male) the girls focused more on the task rather than interacting with other students, whereas when there were all girls, even though the girls remained focused, they interacted with each other more. Girls in the mixed-gender programs distanced themselves during group activities and demonstrated lower levels of class participation than girls in FEMME programs.

Although all students showed significant gains in engineering content knowledge and more positive attitudes toward STEM, during the 2012 evaluation no significant differences were found between male students in the mixed-gender group compared to the all-male group in terms of engineering knowledge, attitudes toward STEM, self-efficacy or their gender attributions of the engineers they drew on the Draw an Engineer Test but there were significant differences for the girls. The girls in FEMME shows significant increases in self-efficacy from the beginning to the end of the program and a significant proportion of them changed the gender of the engineer in their drawing from unidentifiable or male at the beginning to female at the end of the program, while the girls in the mixed gender program showed significant decreases in self-efficacy [9899]. In hindsight, the PI recognized that some of the students (male and female) in the $5^{\text {th }}$ grade program(s) had previously participated in a $4^{\text {th }}$ grade program during the summer of 2011 of a different gender composition than during the summer of 2012, which could have affected the results. 
Comparisons among female-only (FEMME), male-only, and mixed-gender programs, 2015: In 2015, another investigation [101] was designed to be a more rigorous examination of gains in content knowledge and to look more closely at the issues of self-efficacy, gender equity, and qualitative perceptions of engineers, comparing FEMME4 to the all-male and the mixed-gender equivalents (i.e. the post $4^{\text {th }}$ grade environmental science and engineering programs). The mixedgender program had a closer to 50/50 ratio of males to females than the 2012 investigation (48\% female, 52\% male). The girls in FEMME showed greater improvements in engineering content knowledge, computer applications and knowledge of careers in engineering than the girls in the mixed-gender program. The girls in FEMME also showed significant increases in self-efficatcy compared to the girls in the mixed-gender program; the self-efficacy of the girls in the mixedgender program actually decreased. No significant changes were found in the self-efficacy of the male students in either the single- or mixed-gender programs. The girls in FEMME also showed an increase in their perceptions that women can be engineers, evidenced by significant increases in the gender equity subscale of the Middle School Attitudes Middle School Attitudes to Mathematics, Science and Engineering Survey and again, changes in gender attribution of the engineers they drew in the Draw an Engineer Test from unidentifiable or male at the beginning of the program to female at the end of the program. The same changes in the gender attribution of the engineers drawn by the girls in the mixed-gender program were not evident. Notably, none of the male students in any of the programs drew female students at any time. If young boys do not consider that engineers can be female, their interactions with female students during engineering lessons might be negative. The male students may even remark that "engineers are not women" or they could say to a female student "you're not going to be an engineer".

Follow-up 2016: A follow-up study was conducted during the summer of 2016, in which the same evaluation performed during the summer of 2015 was repeated [102]. The summer began with 25 students in the female-only (FEMME) programs, 24 students in the male-only program and in the two mixed-gender programs there were 47 students (24 and 23), for a total of 96 post $5^{\text {th }}$ grade students. Fifty-four were returning students and 42 were new students. Of the 25 girls in the FEMME program, 18 had attended the $4^{\text {th }}$ grade FEMME program, 5 had attended the $4^{\text {th }}$ grade mixed-gender program, and there were 2 new students. One of the girls who had previously attended the $4^{\text {th }}$ grade FEMME program attended one of the mixed-gender programs. Except for the FEMME programs which had approximately $70 \%$ returning students, each of the other programs had approximately $40 \%$ returning students.

The positive effects on female students acquired during the summer of 2015 were sustained through the school year and were still evident from pre-measures for girls who returned during the summer of 2016. At the beginning of the 2016 program, the girls who had attended FEMME4 showed higher levels of self-efficacy and demonstrated a more accurate understanding of what engineers actually do than the girls who had participated in the mixed-gender program. The girls from FEMME gave more correct responses to the knowledge of careers in engineering section of the Attitudes to Mathematics, Science and Engineering Survey than the girls from the mixed-gender program, and the engineers in their drawings were more detailed and more accurate. The engineers were designing and solving problems. Some of the engineers were described as testing a prototype or "helping" make something "better" (improving peoples' lives), which is more consistent with women's preferred career choices, to help improve society. The girls in the FEMME program also showed continued increases in self-efficacy that were not apparent in the male or female students in the other programs. 
The most encouraging results came from an examination of the gender attributions of the engineers in students' drawing. Table I is a summary of the gender attribution students gave to their engineers in the drawings they produced at the beginning of the 2016 program, according to which program they attending during 2015, or they are listed as newlnone. Of the students who attended the mixed-gender program, approximately equal proportions drew male engineers, female engineers, or engineers of unknown gender. The same is true for the new students, with slightly more engineers of unknown gender. None of the male students in any of the programs drew a female engineer. In contrast, most of the girls who attended the FEMME program in 2015 drew a female engineer at the beginning of the 2016 program. Very few girls who attended the mixed-gender program in 2015 drew a female engineer. These results help support the conclusion that attending the $4^{\text {th }}$ grade FEMME program had a positive and sustained effect on girls' perceptions that females can be engineers.

TABLE I

Summary of Engineers' Gender at the start of the 2016 Program based on 2015 Program

Engineer was

\begin{tabular}{|c|c|c|c|}
\hline Single-gender Male & Single-gender Female & & NonelNew \\
\hline
\end{tabular}

Female

Male

13

Unknown

10

5

13

3

2

\section{6}

8

6
10

12

17

Changes in the gender attributions of the engineer from the beginning to the end of the program in relation to students' gender and the type of program for the $20165^{\text {th }}$ grade program; all-male, all female, or mixed-gender; are summarized in Table II. Although many of the male students in the mixed-gender program drew engineers of unknown gender at the beginning and the end of the program, more drew male engineers at the end of the program. Again, none of the male students in either the single-gender or mixed gender programs drew female engineers at any time. Approximately $75 \%$ of the females in the FEMME program drew female engineers at the beginning of the 2016 program and even more drew female engineers at the end of the program.

TABLE II

Summary of Changes in Gender Attributions of Engineers from Drawings, 2016

\begin{tabular}{cccccccccc}
\hline & \multicolumn{3}{c}{ Single-gender } & \multicolumn{3}{c}{ Mixed-gender } \\
Engineer's gender & \multicolumn{2}{c}{ Male } & \multicolumn{2}{c}{ Female } & \multicolumn{3}{c}{ Male } & \multicolumn{2}{c}{ Female } \\
Male & Start & End & Start & End & Start & End & Start & End \\
Female & 10 & 12 & 3 & 1 & & 16 & 20 & 4 & 5 \\
Unknown & 0 & 0 & 17 & 20 & 0 & 0 & 12 & 8 \\
& 14 & 12 & 4 & 3 & 10 & 6 & 3 & 6 \\
\hline
\end{tabular}

More than half of the female students in the mixed-gender program drew female engineers at the beginning of the program, but less than half drew female engineers at the end of the progam. Many of the girls who changed the gender of their engineer drew engineers of unknown gender rather than male engineers. Although they did not depict engineers as male, it appeared that they no longer saw them as female, further suggesting that participation in the FEMME program is important for young girls. More details are reported in [102]. 
The researchers were interested to see what proportion of the girls in the FEMME program returned again in the summer of 2017, whether the positive effects were again sustained, and whether continued participation would have further positive results.

Follow-up 2017: A third year follow-up was conducted during the summer of 2017. Nineteen girls who participated in FEMME5 in 2016 returned during the summer of 2017, but not all attended FEMME6. Of the 25 girls who participated in FEMME6 during the summer of 2017, 15 were returning students. Ten of them had attended FEMME4 and FEMME5 during the summers of 2015 and 2016, respectively. An additional 5 girls had attended FEMME5 during the summer of 2016. There were four girls who attended FEMME5 in 2016 who chose to attend the mixedgender program during 2017. Of those four girls, three had also attended FEMME4. Due to the number of new applicants, in addition to the FEMME program and the single-gender, all-male program, two mixed-gender programs were added with approximately equal proportions of male and female students.

In addition to repeating the same follow-up evaluation(s) performed in 2016, parents of the returning students were asked to respond to a survey regarding their daughter's school performance and interest in a STEM career as part of the application process. The application for returning students included the following three questions; parents were also given space to provide a comment.

- Has your child's grades in mathematics and science improved since attending last summer?

- Has your child's attitude towards their mathematics and science classes improved since attending last summer?

- Has your child expressed an interest in further studies in STEM?

Eighty-three percent (84\%) of the parents whose daughters returned for the summer of 2017 reported that their daughters' grades in mathematics and science had improved since attending the FEMME program in 2016. A few of the comments include;

- My child's grade in science improved after attending NJIT last summer. She went from a B student to an A+ student.

- She had B's last year and now she has all A's

- She was placed a grade ahead in 7th grade math even though she is a 6th grader. Her grades did go down first term but are going back up.

Seventy-four percent (74\%) of the parents reported that their daughters' attitude towards their mathematics and science classes improved since attending the FEMME program in 2016. A few of the comments include;

- She is now more positive and works hard on her stuff and is very independent.

- Science was just "OK" last year. Now it's her favorite subject.

- She's much more knowledgeable about math, science and tech and has more confidence in relation to these areas.

And ninety-six percent (96\%) of the parents reported that their daughters had expressed an interest in further studies in STEM since attending the FEMME program in 2016. A few of the comments include;

- She likes music and is very interested in the social sciences. This experience at NJIT has shown her another option. Not sure which one she will pursue after 12 th grade. 
- Not verbally but her actions speak loudly.

- She has always enjoyed math but now has showed a greater interest in the subject. She hopes and is excited to learn more and carry that for her future endeavors.

The gender attributions of the engineers in students' drawing were examined at the start of the 2017 program also. Table III is a summary of the gender attribution students gave to their engineers according to which program they attending during 2016, or they are listed as new if they were new in 2017. All of the girls who attended FEMME6 during the summer of 2016 drew a female engineer except for one; although her engineering was "designing a bridge", there was no indication of the gender, so it was coded as unknown. None of the girls drew a male engineer. Of the students who attended the mixed-gender programs in 2016, most drew male engineers, less than $20 \%$ drew female engineers.

Still, none of the male students drew female engineers. One male student did describe what the engineer was doing as "he/she is building a robot to help senior citizens", BUT the drawing of the engineers was clearly masculine. One of the 5 female students who had attended a mixedgender program in 2016 and drew a female engineer actually referred to the engineer as "he" in the sentence. So although her vision of the engineer was female, when she described what the engineer was doing, she said "he is building a robot". At the end of the program, this same girl drew "symbols to represent" three different fields of engineering with no actual engineer in her drawing, so her engineer was coded as unknown.

Only 20\% of the new female students drew female engineers; most of them drew male engineers or engineers of indeterminate gender. This is further disappointing because many of the engineers depicted in the new students' drawing showed an understanding of what engineers do, using the words "designing" or "solving problems", so they had some exposure to engineering education, and most saw engineers as male, further emphasizing the need to educate young students that women can be engineers.

TABLE III

Summary of Engineers' Gender at the start of the 2017 Program based on 2016 Program

\begin{tabular}{|c|c|c|c|c|}
\hline Engineer was & $\underline{\text { Single-gender Male }}$ & $\underline{\text { Single-gender Female }}$ & $\underline{\text { Mixed-gender }}$ & $\underline{\text { NonelNew }}$ \\
\hline Female & - & 18 & 5 & 7 \\
\hline Male & 8 & - & 20 & 15 \\
\hline Unknown & 4 & 1 & 3 & 13 \\
\hline
\end{tabular}

Other results that are more positive: the four girls who had previously attended FEMME but had switched to a mixed-gender program continued to draw female engineers, helping to account for the high numbers of girls in the mixed gender who drew female engineers at the beginning and the end of the program in 2017 (see Table VI). Their prior experience appears to have been was retained and they continue to see engineers as female. Most of the other girls who drew female engineers at the beginning and the end of the program were new students, not students who had attended the program in 2016. It appears that these girls had some prior exposure to engineering education because their drawings were also accurate in terms of what engineers do, describing what the engineer in their draw was doing with words like "designing, improving, discovering, 
testing", whereas the girls who drew male engineers more often described their engineers as "fixing cars, trains", or not writing anything, just drawing someone working with their hands doing something that was not necessarily obvious.

TABLE IV

Summary of Changes in Gender Attributions of Engineers from Drawings, 2017

\begin{tabular}{cccccccccc} 
& \multicolumn{3}{c}{ Single-gender } & \multicolumn{4}{c}{ Mixed-gender } \\
& \multicolumn{2}{c}{ Male } & \multicolumn{3}{c}{ Female } & \multicolumn{3}{c}{ Male } & \multicolumn{2}{c}{ Female } \\
Engineer's gender & Start & End & Start & End & Start & End & Start & End \\
Male & 19 & 20 & 5 & 3 & & 14 & 10 & $7^{*}$ & 9 \\
Female & - & - & 16 & 22 & - & - & 13 & 10 \\
Unknown & 5 & 4 & 4 & - & 9 & 13 & 6 & 6 \\
\hline
\end{tabular}

* One of the girls who had previously been in a mixed-gender program dropped out.

Students' drawings from the beginning of the program are summarized in Table V, again according to which program they attended in 2016 or if they were new students. Most of the drawings produced by the girls who had attended the FEMME programs showed accurate portrayals of what engineers do (designing, creating, solving problems, or help/improving). Many of the new students said their engineers were fixing something. Comparing the returning students' drawing to the new students drawings showed that the effects of attended in either 2016 or 2016 and 2015 (learning) were sustained.

TABLE V

Summary of What Engineers in Pre-Drawings were doing based on 2016 Program

\begin{tabular}{|c|c|c|c|c|}
\hline \multirow{2}{*}{\multicolumn{5}{|c|}{ Engineer was }} \\
\hline & & & & \\
\hline Designing $\backslash$ Creating $\backslash$ Inventing & 2 & 7 & 7 & 5 \\
\hline Building Model\Prototype & - & - & 2 & - \\
\hline Solving Problems & 1 & 1 & 1 & - \\
\hline Experiment $\backslash$ Testing & 2 & - & 6 & 2 \\
\hline Helping\Improving & 1 & 4 & 2 & - \\
\hline Coding $\backslash$ Programing computer & 2 & 3 & 2 & 2 \\
\hline Fixing & 5 & 3 & 2 & 9 \\
\hline Making \Building|working & 2 & 2 & 3 & 2 \\
\hline Flying rocketlplane & 2 & - & 1 & 2 \\
\hline Holding Toolslworking with hands & 6 & 2 & - & 5 \\
\hline Studying $\backslash$ Explaining $\backslash$ Thinking & 1 & 2 & 1 & 2 \\
\hline Building robot & - & 1 & 1 & 2 \\
\hline Drawing blue prints & - & - & - & 1 \\
\hline
\end{tabular}




\section{Discussion}

Continued follow-up of students who continue to participate in engineering summer enrichment programs offered by the Center for Pre-College Programs at NJIT demonstrate that the programs are effective in increasing all students' knowledge of engineering and careers in engineering. All students who participated had positive attitudes toward engineering and gave more correct responses to the knowledge of careers in engineering section of the Attitudes to Mathematics, Science and Engineering Survey. Drawings of engineers by returning students in 2017 were more detailed and more accurate than those drawn by new students. Regardless of the gender of the engineers in the students' drawing, the drawings that students produced, male and female, showed that students' conceptions of engineers and what they actually do are developing accurately. At the beginning of the program, many of the new students drew engineers that were "fixing cars" or just standing there with tools in their hands. Comparing details of the drawings from returning/continuing students to those the new (first-time) students, one can draw the conclusion that continued participation is beneficial to students, both male and female in terms of engineering knowledge.

Participation in the single-gender, all female program FEMME shows continued benefits for girls in terms of self-esteem and the knowledge that girls can be engineers. Positive effects on female students acquired during the summer of 2015 were sustained through the school year and evident during the summer of 2016. These effects were further sustained and still evident for the female students who returned again for a third summer during the summer of 2017. Results of a parent survey underscore these results, as $83 \%$ of the parents of girls who had previously attended the FEMME program reported that grades in mathematics and science had improved, $74 \%$ reported that the girls' attitude(s) toward math and science class had become more positive, and $96 \%$ reported that she had expressed an interest in further STEM studies since attending the previous summer.

\section{References}

[1] Sargent, J. F. (2014). The U.S. Science and Engineering Workforce: Recent, Current and Projected Employment, Wages and Unemployment. Congressional Research Service. https://fas.org/sgp/crs/misc/R43061.pdf

[2] Bureau of Labor Statistics (2017). https://www.bls.gov/ accessed August 29, 2017.

[3] JerseyCan, (2017). "Preparing the Children of Today for the Jobs of Tomorrow, A Window into STEM Education in New Jersey", The New Jersey Campaign for Achievement Now. www.jerseycan.org

[4] Levine, D. (1984). An Innovative Approach to Attract Young women to Careers in Engineering and Science", Engineering Education, Dec. pp. 162-164.

[5] Levine, D. (1985). “Adding a Women's Touch", The Science Teacher, Sept. pp. 25-29.

[6] Levine, D. (1985). "Encouraging Young Women to Pursue Science and Engineering Careers through Chemistry", Journal of Chemical Education, Vol 62(10), 837-839.

[7] President's Council of Advisors on Science and Technology (PCAST). (February, 2012). Engage to Excel: Producing one Million Additional College Graduates with degrees in Science, Technology, Engineering and Math. Download from http://www.whitehousegov/ostp/pcast. 
[8] National Science Board. (2016). Science and engineering indicators 2016, Arlington, VA: National Science Foundation, 2016, (NSB20161.pdf).

[9] National Academy of Engineering (NAE) Committee on Engineering's Grand Challenges. (2012). Grand Challenges for Engineering, from http://www.engineeringchallenges.org/cms/challenges.aspx

[10] Kimmel, H., Carpinelli, J., Burr-Alexander, L. and Rockland, R. (2006). Bringing Engineering into K-12 Schools: A Problem Looking for Solutions, Proceedings of the 2006 American Society of Engineering Education Annual Conference \& Exposition, Chicago, IL. June.

[11] National Academy of Engineering (NAE) Committee on Engineering's Grand Challenges. (2012). Grand Challenges for Engineering, from http://www.engineeringchallenges.org/cms/challenges.aspx

[12] Samson, C., Sullivan, J., Reitsman, R. F. and Soltys, M. (2015). The Relevance of K-12 Engineering Curricula to NGSS: An Analysis of TeachEngineering NGSS Alignment, Proceedings of 2015 American Society of Engineering Education Annual Conference \& Exposition, Seattle, WA, June.

[13] Rockland, R., Bloom, D., Carpinelli, J., Burr-Alexander, L., Hirsch, L.S., and Kimmel, H. (2010). Advancing the "E" in K-12 STEM Education. Journal of Technology Studies, XXVI, p.53-61.

[14] Camera, L. (2015). Women Still Underrepresented in STEM fields, U.S. News and World Report, October, 21, 2015

[15] D'Onofrio, K. (2015). http://www.diversityinc.com/news/women-minorities-continuallyleft-behind-in-stemjobs/, July 20, 2015.

[16] Beede, D., Julian, T., Langdon, D., McKittrick, G., Khan, B., \& Doms, M. (2011). Women in STEM: A gender gap to innovation. Retrieved October 28, 2015 from http://www.esa.doc.gov/sites/default/files/reports/documents/ womeninstemagaptoinnovation8311.pdf

[17] National Science Foundation, (2017). Women, Minorities, and Persons with Disabilities in Science and Engineering, Arlington, VA, NSF 17-310, January, 2017.

[18] Bidwell, A. (2105). STEM Workforce No More Diverse Than 14 Years Ago, U.S. News and World Report, February, 24, 2015

[19] Massi, L., Reilly, C., Johnson, D. and Castner, L. (2012). Expanding Your Horizons: The Impact of a One-Day Conference on Middle School Girls' and Parent's Attitudes Toward STEM Careers, Proceedings of the 2012 American Society of Engineering Education Annual Conference \& Exposition, San Antonio, TX, June.

[20] Kimmel, H., Burr-Alexander, L., Hirsch, L.S., Rockland, R., Carpinelli, J., and Aloia, M. (2014). "Pathways to Effective K-12 STEM programs". Proceedings of the 2014 Frontiers in Education Annual Conference, Madrid, Spain.

[21] President's Council of Advisors on Science and Technology (PCAST). (September, 2010). Prepare and Inspire: K-12 Science, Technology, Engineering and Math (STEM) education for America's Future. Download from http://www.whitehousegov/ostp/pcast.

[22] Widener, A. (2014). A New Standard. Chemical \& Engineering News, September, 92 (35), 43-45.

[23] Gewertx, C. (2014). Teachers Feel Ill-Prepared for Common-Core Despite Training, Education Week, August 20, 2014, 34 (1), pg. 9. http://www.edweek.com/ew/articles/2014/08/20/01teachers.h34.html 
[24] Tran, N. A. and Nathan, M. J. (2010). An Investigation of the Relationship between PreCollege engineering studies and student achievement in Science and Mathematics. Journal of Engineering Education, 99(2), 143-157.

[25] Samson, C., Sullivan, J., Reitsman, R. F. and Soltys, M. (2015). The Relevance of K-12 Engineering Curricula to NGSS: An Analysis of TeachEngineering NGSS Alignment, Proceedings of 2015 American Society of Engineering Education Annual Conference \& Exposition, Seattle, WA, June.

[26] Capobianco, B. M., Diefes-Dux, H. A., Mena, I. and Weller, J. (2011). What is an Engineer? Implications of Elementary Student Conceptions for Engineering Education. Journal of Engineering Education, 100(2), 304-328.

[27] Richards, L., Hallock, A. and Schnittka, C. (2007). Getting them Early; Teaching engineering Design in Middle School, Journal of Engineering Education, 23(5), pp. 874883.

[28] Geisinger, B. N. and Raman, D. R. (2013). Why They Leave: Understanding Student Attrition from Engineering Majors, Iowa State University Digital Repository, http://lib.dr.iastate.edu/abe_eng_pubs/607/

[29] Carpinelli, J. D., Burr-Alexander, L. E., Hanesian, D., Kimmel, H. and Sodhi, R. S. (2004). "The Pre-Engineering Instructional and Outreach Program at New Jersey Institute of Technology". Proceedings of the International Conference on Engineering Education, Gainesville, FL, Oct. 2004.

[30] Kimmel, H., Carpinelli, J., Burr-Alexander, L., and Rockland, R. "Bringing Engineering into K-12 Schools: A Problem Looking for Solutions?" Proceedings of the 2006 ASEE Annual Conference, Chicago, IL, June 2006.

[31] USNEWS (2015). A look at Minorities in STEM, www.USNEWS.com accessed October 29, 2015.

[32] Layton, L. (2013). National high school graduation rates at a four-decade high. The Washington Post, Education, January 22.

[33] Brown, E. (2015). College enrollment rates are dropping, especially among low-income students. The Washington Post, Education, November 24.

[34] National Women's Law Center. (2012). The Next Generation of Title IX: STEM - Science, Technology, Engineering and Mathematics. www.nwlc.org

[35] National Academy of Engineering. (2008). Changing the Conversation: Messages for Improving Public Understanding of Engineering, The National Academies Press, Washington, D.C.

[36] Geisinger, B. N. and Ramen, D. R. (2013). Why They leave: Understanding Student Attrition from Engineering Majors, International Journal of Engneering Education, 29(4), 2013, pp. 914-925.

[37] Hill, C., Corbett, C. and St.Rose, A. (2010). Why so Few? Women in Science, Technology, Engineering and Mathematics; American Association of University Women; www.aauw.org

[38] Vanasupa, L., Chen, K. and Breitenbach, K. (2008). A Design Guide to Retain Female (and Male) Students in Engineering. Paper Presented at the $38^{\text {th }}$ annual ASEE Frontiers in Education Conference, Saratoga Springs, NY.

[39] Gandara, P. (2015). Fulfilling America's Future: Latinas in the U.S., 2015. The White House Initiative on Educational Excellence for Hispanics.

[40] National Women's Law Center. (2015). Unlocking Opportunity for African American Girls, A Call to Action for Educational Equity. www.nwlc.org 
[41] Erling,S. and O'Reilly, J. (2009). Single-Sex Schools: A Review of the Literature, Organizational Development/Research and Information Services, Toronto District School Board.

[42] National Education Association, Research Spotlight on Single-Gender Education. Accessed December 2012. Retrieved December 5, 2012 from www.nea.org

[43] Mead, S. (2006). The evidence suggests otherwise: The truth about boys and girls. Education Sector. Retrieved November 2012, from www.educationsector.org

[44] King, K. and Gurian, M. (2006). Teaching to the Minds of Boys. Educational Leadership,64(1),56-61.

[45] National Education Association, Research Spotlight on Single-Gender Education. Accessed September 19, 2017 from http://www.nea.org/tools/17061.htm

[46] Sadker, D. and Zittleman, K. (2005). Closing the gender gap - again! Just when educators thought it was no longer an issue, gender bias is back in a new context. Principal, 84(4), 18-22.

[47] Demers, S. and Bennett, C. (2007). Single-sexclassrooms. Monographs of The Literacy and Numeracy Secretariat, Ontario Ministry of Education (No. 4).

[48] Taylor, D. and Lorimer, M. (2003). Helping boys succeed. Educational Leadership, 60(4), 68-70.

[49] Mael, F. A., Alonso, A., Gibson, D., Rogers, K. and Smith, M. (2005). Single-sex versus co-educational schooling: A systematic review. U.S. Department of Education, Office of Planning Evaluation and Policy Development, Washington, D.C. Document No. 2005-01.

[50] Bracy, G. (2006). Separate but superior? A review of issues and data bearing on single-sex education. Arizona State University, College of Education, Education Policy Research Unit. Retrieved November 2012, from http://epicpolicy.org/files/EPSL-0611-221-EPRU.pdf

[51] Salomone, R. (2006). Single-sex programs: Resolving the research conundrum. Teachers College Record, 108(4), 778-803.

[52] Protheroe, N. (2009). Single-sex classrooms. Principal,88(5), 32-35.

[53] Koppel, N., and Muldrow, D. (2001). "A First Step for Women into the Engineering Pipeline". Proceedings of the $31^{\text {st }}$ ASEE/IEEE Frontiers in Education Conference, Reno, NV, October 2001.

[54] Koppel, N., Cano, R., Heyman, S. (2002). "An Attractive Engineering Option for Girls" Proceedings of the $32^{\text {nd }}$ ASEE/IEEE Frontiers in Education Conference, Boston, MA, November 2002.

[55] Koppel, N. B., Cano, R. M., Heyman, S. B., and Kimmel, H. (2003). "Single Gender Programs: Do they Make a Difference?" Proceedings of the $33^{\text {rd }}$ ASEE/IEEE Frontiers in Education Conference, Boulder, CO, November 2003.

[56] Shapiro, M., Grossman, D., Carter, S., Martin, K., Deyton, P. and Hammer, D. (2015). Middle School Girls and the "Leaky Pipeline" to Leadership, Middle School Journal, May, pp. 3-13. www.amle.org

[57] Meyer, P. (2008). Learing separately: The case for single-sex schools. Education Next, 8(1), 10-21.

[58] Hossler, D., Schmit, J. and Vesper, N. (1999). "Going to College: How Social, Economic and Educational Factors Influence the Decisions Students Make”. Baltimore, MD: Johns Hopkins University Press.

[59] Gibbons, M. M. and Borders, L. D. (2010). A Measure of College-Going Self-Efficay for Middle School Students, Professional School Counseling, 13(4), pp. 234-243. 
[60] Archer, L., DeWitt, J., Osborne, J., Dillon, J., Willis, B. and Wong, B. (2013). “ 'Not girly, not sexy, not glamorous': primary school girls' and parents' constructions of science aspirations", Pedagogy, Culture \& Society, Vol. 21, pp. 171-194.

[61] Gilson, J. E. (1999). "Single-Gender Education versus Coeducation for Girls: A study of Mathematics Achievement and Attitudes toward Mathematics of Middle-School Students", Paper presented at the Annual Meeting of the American Educational Research Association, Montreal, Quebec, Canada, 1999.

[62] National Commission on Mathematics, Science and Technology, (2000). "Before it's too Late: A Report to the Nation from the National Commission on Mathematics and Science Teaching for the 21 st Century", www.phystec.org/items/details.cfm?ID=4059

[63] Blaisdell, S. (2000). "Students' decision to enter engineering: How men and women differ." Proceedings of the WEPAN Annual Conference, pp. 243-251.

[64] Microsoft (2017). The Exact Age When Girls Lose Interest in Science and Math, Tech30 survey.

[65] Jacobs, J. E., Hyatt, S., Osgood, W. D., Eccles, J. S. and Wigfield, A. (2002). Changes in Children's Self Competence and Values: Gender and Domain Differences across Grades one through twelve. Child Development, 73 (2), 509-527.

[66] Wang, M. T. and Degol, J. (2013). Motivational Pathways to STEM Career Choices: Using Expectancy-value Perspective to Understand Individual and Gender Differences in STEM fields, Developmental Review, 33, pp. 304-340.

[67] Pittenger, A. (2017), "Girls are still less interested in STEM careers than boys. Here's what Tucson is doing about it". http://tucson.com/thisistucson/schools/girls-are-still-lessinterested-in-stem-careers-than-boys/article_b9d2f8a6-551d-11e7-8ebb-7b86e39f2ebb.html

[68] Conlin, M. (2003) The New Gender Gap, Business Week, May 26.

[69] Broadley, K. (2015). Entrenched Gendered Pathways in Science, Technology, Engineering and Mathematics: Engaging Girls Through Collaborative Career Development, Australian Journal of Career Development, Vol. 24(1), pp.27-38.

[70] Hartman, H. "A gender lens on Rowan University's College of engineering", Joint NAMEPA/WEPAN National Conference, Alexandria, Virginia, Apr. 21-24, 2001.32-38.

[71] Gibbons, M. (2006). Women in engineering, ASEE Prism, 15(5), January 2006.

[72] Peterson, K. (2016). The National Girls Collaborative Project: Using Collaboration to Increase Impact, Techniques, May, pp. 35-38. www.acteonline.org

[73] Campbell, B. R., Robb, S. M. and Abbott, S. (2104). Impact of a 5-week Collegiate Level Residential STEM Summer Program on Secondary School Students, Proceedings of the $121^{\text {st }}$ ASEE Annual Conference \& Exposition, Indianapolis, IN, June.

[74] Chopra, S., Bertoline, G. R., and Laux, C., M. (2012). Finding What Women Want: Developing Strategies to Increase Recruitment and Retention of Women. Proceedings of the 2012 American Society of Engineering Education Annual Conference \& Exposition, San Antonio, TX. June.

[75] Hirsch, L. S., Berliner-Heyman, S., Cano, R., Kimmel, H. and Carpinelli, J. (2011). Middle School Girls' Perceptions of Engineers Before and After a Female Only Summer Enrichment Program. Proceedings of the 2011 ASEE Frontiers in Education Annual Conference, Rapid City, SD, October.

[76] Plant, E. A., Baylor, A. L., Doerr, C. E. and Rosenberg-Kima, R. B. (2009). Changing Middle-School Students' Attitudes and Performance Regarding Engineering with computerbased Social Models, Computers \& Education, 53, pp. 209-215. 
[77] Dell, E. M., Christman, J. and Garrick, R. D. (2011). Assessment of an Engineering Technology Outreach Program for $4^{\text {th }} 7^{\text {th }}$ Grade Girls, American Journal of Engineering Education, 2(1), pp.19-33.

[78] Dave, V., Blasko, D. Holiday-Darr, K., Kremer, J. T., Edwards, R., Ford, M., Lenhardt, L. and Hido, B. (2010). Re-enJeaneering STEM Education: Math options Summer Camp, The Journal of Technology Studies, 1, pp.35-45.

[79] Renninger, K. A., Hidi, S. and Krapp, A. (1992). "The Role of Interest in Learning and Development", Editors, Erlbaum, Hillsdale, NJ.

[80] Hirsch, L. S., Cano, R. Berliner-Heyman, S., and Cusack, J. L. (2016). "Introducing Young Girls to Engineering through Summer Enrichment Programs. Transactions on Techniques in STEM Education, Vol. 2(1), pp. 75-88.

[81] Worell, J. (2002). Encyclopedia of Women and Gender: Sex Similarities and Differences. Academic Press, San Diego, Calif.

[82] Hersh, M. (2000). The changing Position of Women in Engineering Worldwide, IEEE Transactions on Engineering Management. 47(3), pp. 345-359.

[83] Modi, K., Schoenberg, J. and Salmond, K. (2012). Generation STEM; What Girls Say About Science, Technology, Engineering and Math, Girls Scout Research Institute, pp. 144.

[84] Kerkhoven, A. H., Russo, P., Land-Zandstra, A. M.Saxena, A. and Rodenburg, J. (2016). Gender Stereotypes in Science Education Resources: A Visual Content Analysis, PLOS ONE, November 16, 2016, http://journals.plos.org/plosone/article?id=10.1371/journal.pone.0165037

[85] Hughes, W. J. (2002). Gender Attributions of Science and Academic Attributes: An examination of Undergraduate Science, Mathematics, and Technology Majors. Journal of Women and Minorities in Science and Engineering, 8(1), pp. 53-65.

[86] Artino, A. R. (2012). Academic Self-Efficacy: From Educational Theory to Instructional Practice, Perspectives on Medical Education, May, 1(2), pp. 76-85.

[87] Edzie, R. L. and Alahmad, M. (2013). Exploring the Factors that Motivate Female Students to Enroll and Persist in a Collegiate STEM Degree Program, Proceedings of the 2013 IEEE GCC Conference and Exhibition, November 17-20, Doha, Qatar. pp.419-424

[88] Edzie, R., Alahmad, A. and Alahmad, M. (2015). Understanding the Factors that Affect Female Enrollment and Retention in Collegiate STEM Programs, Proceedings of the $8^{\text {th }}$ IEEE GCC Conference and Exhibition, February 1-4, Muscat, Oman.

[89] Godwin, A. and Potvin, G. (2015). Fostering Female Belongingness in Engineering through the Lens of Critical Engineering Agency, International Journal of Engineering Education, 31(4), pp. 938-952.

[90] Griffth, A. (2010). Persistence of Women and Minorities in STEM Field Majors: Is it the School that matters? Economics of Education Review, Vol. 29, pp. 911-922.

[91] Burns, H. D., Lesseig, K. and Staus, N. (2016). Girls' Interest in STEM, Proceedings of the 2016 IEEE Frontiers in Education Conference, October, Erie, PA.

[92] NGSS Lead States (2013). Next Generation Science Standards: For States, By State. Washington, DC: The National Academies Press. Available at http://www.nextgenscience.org/

[93] Koppel, N. B., Cano, R. M., Heyman, S. B., and Kimmel, H. (2003). "Single Gender Programs: Do they Make a Difference?" Proceedings of the $33^{\text {rd }}$ ASEE/IEEE Frontiers in Education Conference, Boulder, CO, November 2003. 
[94] Gibbons, S., Koppel, N., Berliner-Heyman, S., Kimmel, H. and Cano, R. (2004). "Evaluation of Summer Enrichment Programs for Womens' Students", Proceedings of the 2004 American Society for Engineering Education Annual Conference \& Exposition.

[95] Bloom, J., Hirsch, L., Kimmel, H., Rockland, R. (2006). "A Study of the Impact of Enrichment Programs on Girls' Attitudes Towards Engineering”. Proceedings of the 2006 International Conference on Engineering Education, San Juan, PR, July 2006.

[96] Hirsch, L. S., Carpinelli, J., Kimmel, H., Rockland, R. and Bloom, J. (2007). The Differential Effects of Female Only Vs, Co-Ed Enrichment Programs on Middle School Students' Attitudes Toward Science, Mathematics and Engineering, Proceedings of the 2007 ASEE Annual Conference, Honolulu, HI, June 2007.

[97] Hirsch, L. S., Berliner-Heyman, S., Cano, R., Kimmel, H. and Carpinelli, J. (2011). Middle School Girls' Perceptions of Engineers Before and After a Female Only Summer Enrichment Programg, Proceedings of the $41^{\text {st }}$ ASEE/IEEE Frontiersin Educationl Conference, Rapid City, SD., Oct. 2011.

[98] Hirsch, L. S., Berliner-Heyman, S., Cano, R., Carpinelli, J., Kimmel, H. and Romero, S. (2013). "A Comparison of Single \& Mixed Gender Engineering Enrichment Programs for Elementary Students". Proceedings of the 2013 Frontiers in Education Annual Conference, Oklahoma City, OK.

[99] Hirsch, L. S., Berliner-Heyman, S., Cano, R., Carpinelli, J. and Kimmel, H. (2014). “The Effects of Single vs. Mixed Gender Engineering Enrichment Programs on Elementary Students' Perceptions of Engineers", Proceedings of the 2014 American Society for Engineering Education Annual Conference, Indianapolis, IN.

[100] Hirsch, L. S., Carpinelli, J. D., Kimmel, H., Rockland, R. and Bloom, J. (2007). The Differential Effects of Pre-engineering Curricula on Middle School Students' Attitudes to and Knowledge of Engineering Careers. Proceedings $37^{\text {nd }}$ ASEE/IEEE Frontiers in Education Conference, Milwaukee, WI, October.

[101] Hirsch, L. S., Berliner-Heyman, S. and Cano, R. (2016). "Comparisons of a Female-Only, Male-Only, and Mixed-Gender Engineering Enrichment Program for 4th Graders", Proceedings of the 2016 American Society for Engineering Education Annual Conference, New Orleans, LA.

[102] Hirsch, L. S., Berliner-Heyman, S., Cano, R. and Cusack, J. L. (2017). "The Effectiveness of Single-gender Engineering Enrichment Programs: A Follow-up Study”, Paper presented at the 2017 American Society for Engineering Education Zone II Conference, San Juan, PR.

[103] Gibbons, S. J., Hirsch, L. S., Kimmel, H., Rockland, R. and Bloom, J. (2004). "Middle School Students Attitudes to and Knowledge about Engineering," Proceedings of the 2004 International Conference on Engineering Education, Gainesville, FL.

[104] Knight, M. and Cunningham, C. M. (2004). "Draw an engineer test (DAET): development of a tool to investigate students' ideas about engineers and engineering”. In: Proceedings of the 2004 ASEE annual conference and exposition, Salt Lake City, Utah, June, 2004 